Canadian Journal of Family and Youth, 11(1), 2019, pp. 295-299

ISSN 1718-9748@ University of Alberta

http://ejournals,library,ualberta.ca/index/php/cjfy

\title{
O'Sullivan, Patrick and Joyce, Gare (2015). Breaking Away: A Harrowing True Story of Resilience, Courage, and Triumph. Toronto: HarperCollins.
}

\author{
Reviewed by: Angela Adomonis, MacEwan University
}

In the book "Breaking Away" by Patrick O'Sullivan and Gare Joyce, Patrick recounts his story of growing up with an abusive father who went to extreme lengths with the intent to make him into an NHL star. Patrick was born to John O'Sullivan and his wife Cathie O'Sullivan in February of 1985. Patrick's father was a failed hockey player, he simply did not have the skill to make it as a professional. He attributed his failure to a late start in the game; the fault of his own father. Once Patrick took an interest in hockey, it became his father's obsession. He was determined to make Patrick the star that he was never able to be and would do anything in his power to make that happen.

Patrick started playing hockey at the age of six and was a natural. Patrick indicated that his training took over his life. His father forced him to practice at any free moment, leaving him no time to socialize with other kids and make friends. His father started to become more verbally and physically abusive, using derogatory language and slapping the back of Patrick's head as a punishment. He would scream at Patrick from behind the boards and criticize everything he did on the ride home. As Patrick grew older, he would be pulled out of school on the days his father did not work to go practice. His father's obsession with his training became so intense that he would be woken up in the middle of the night and put through rigorous physical workouts. He would be beaten or locked outside in the cold if he was not working hard enough and even be 
forced to run behind the van on their way home after games.

For the next few years, Patrick would continue to thrive in the hockey scene. Patrick's father made him play on a different team every season, always making sure there was a new challenge in hopes of advancing his career. He played at various skill levels and against all ages; he was always one of the best players. He attracted the attention of agents, which allowed him to play with the USA Hockey under-17 program and got drafted to the OHL. Although he was doing phenomenal on the ice, Patrick shares that the abuse was only getting worse:

Every year he was ramping it up: a slap in the face when I was eight; a slap with more force and a kick in the ass when I was nine; a punch when I was ten; a big right hook on my jaw and a kick in the gut or ribs until I was gasping when I was eleven, twelve, and thirteen. And if that weren't enough, he'd grind a cigarette out in my face or come up with other ways to punish and humiliate me (p. 69).

Patrick's father was getting to live vicariously through Patrick, “The league that didn't want my father when he was eighteen seemed to be bending down to kiss his ass." (p. 103). When Don Cherry, the owner of the IceDogs, wanted to draft Patrick, his father was star-struck. Everything he had dreamed of in his own career was becoming a reality for Patrick and it was all thanks to him. Although the IceDogs were stationed in Mississauga, Patrick was allowed to live with his father's brother. This way, Patrick's father could still exert control over him. He would phone Patrick and yell at him for hours, he had a key to the townhouse, so he could come over after games and force Patrick to workout; the abuse was worse then ever before.

On January 4, 2002, Patrick decided he was done with the abuse. Patrick had been playing poorly during this specific game, and his father was more agitated then usual. After the game Patrick attempted to avoid him, but his father dragged him off his team's bus and threw 
him in the back of their van. As his father drove, he kept saying, "I brought you into this world and I can take you out." (p. 134). Once they arrived at Patrick grandparent's house where the family was staying, Patrick got out of the car and took a stand against his father. His father proceeded to beat him worse then ever before. Once his father had nothing left in him, Patrick got up, went inside, called the police, and his father took off (pp. 121-140). Patrick had a run-in with his father years later after one of his minor league games. His father acted casual, as though nothing had happened years ago, but Patrick ignored him. Whether or not his father is delusional, he does not take responsibility for what happened, saying that he "has no regrets" and "wouldn't do anything different" when asked about what happened between him and Patrick (p. 161).

Patrick's father was charged with assault, issued a restraining order, and Patrick's mother divorced him. Although he would still try to sneak into Patrick's games, he no longer had control over his life. Patrick continued with hockey and made it to the NHL draft. Before the draft, Patrick had done an interview with ESPN about his childhood to try to set the record straight. While being interviewed by potential teams, the subject of his past was brought up frequently. Although Patrick was ranked as the fourteenth best player by CSS, he was picked in the secondround draft at the number fifty-six spot. This was a huge disappointment for Patrick because he had the skills of a great hockey player, but teams were unsure about his psychological well-being and did not want to deal with the baggage of his past. Although his father was out of his life, the effects of his traumatic past were still following him.

Patrick's career never took off in the NHL. Although he would play in over four-hundred games and in the World Under-20s, he also played in the minors and was traded amongst teams. Whether it was due to his past or other factors, he never had stability in the game. Not having 
any luck in the NHL, he tried playing in Europe. Just after a short time there, Patrick knew he was done with professional hockey at twenty-seven.

Not only had the abuse taken a tole on his professional life, but his personal life as well. Patrick has no relationship with his mother. She had never made a serious attempt at stopping the abuse and financially abused Patrick whilst he was making money in the NHL. Patrick met his wife Sophie back when he was playing in the OHL. His career made the relationship difficult, but it was also difficult for Patrick to open up to her and be emotionally vulnerable. Patrick wanted to be able to be a good husband and a good father to his two sons. After his professional hockey career was over, he sought out the help of a psychologist. He was diagnosed with PTSD and started to work on his recovery.

The booking "Breaking Away," although it is one of the more extreme cases, gives an inside look into how far some parents will go to try and further their child's athletic careers. Through his compelling and emotional story, Patrick does an excellent job at showing the ugly truth of growing up in an abusive environment, while also sharing a story of resilience. He shows that there is still hope for a life after abuse, but there are also lasting effects that abuse has on its victims. However, the book does get a bit repetitive as Patrick circles back to events of his past multiple times. This also creates problems of the story jumping between the past and the present which can be confusing and hard to follow at times.

This book would be an excellent read for sport psychologist or others working with children affected by child abuse. Patrick also mentions his reasons for writing this book and who he believes could benefit from reading it. Firstly, to encourage parents to look at how they are raising their children. He hopes that in reading this book, parents will not make the same 
mistakes his father did and cross the line when it comes to motivating their children. Secondly, he hopes that adults may be able to identify red flags of child abuse. Many adults in his life, such as his coaches, did not act on some of the warning signs they noticed. Patrick hopes that his book will create more awareness and encourage adults to step in in if they notice a pattern of abuse.

Finally, he is writing this book to let other victims of abuse know they are not alone and to not be afraid to seek professional help to heal the damage that has been done. 